\title{
Encouraging Critical Thinking and Professional Reading with Literacy Bags
}

\author{
Jackie Greene and Linda C. Serro*
}

Florida Gulf Coast University, 10501 FGCU Blvd S., Fort Myers, FL 33965, USA

\begin{abstract}
Students enrolled in college courses are typically expected to read one or more textbooks per course. While the course text may be comprehensive, the author's approach may be narrow in focus, disregarding diverse perspectives on the subject. In addition, the limited genre presented in textbooks (i.e., nonfiction, expository) is not likely to encourage a desire for professional reading in students. To address these issues, two faculty members incorporated a Literacy Bag Project into their education courses at both graduate and undergraduate levels. The Literacy Bag activity involves students reading diverse genres in a variety of texts throughout the semester. Students select a different book each week, read one chapter/section, and reflect on the reading via journal writing and/or verbal discussions. This study examined students' perception of the Literacy Bag activity, as well as impact on critical thinking and professional literacy. Results indicate students at both the graduate and undergraduate levels: (1) plan to continue professional reading beyond the course; (2) engage in critical thinking; (3) enjoyed the activity and recommended the activity continue to be implemented. Analysis of student responses identified critical themes for success with the Literacy Bag activity: choice, perspective sharing, motivation, and classroom applications.
\end{abstract}

Keywords: Aesthetic stance, aliteracy, classroom applications, choice, college students, perspective sharing, professional reading, motivation.

\section{INTRODUCTION}

Enter a teacher preparation classroom and ask the teacher candidates if they like to read. As Literacy faculty members and researchers we were alarmed at their responses. We heard things like, "I don't have time to read". "I've never been a reader". "I am interested in other things". What was even more disturbing was that most of these students were enrolled in an undergraduate or graduate reading methods course! One of the most alarming trends reported in the National Endowment for the Arts meta-analysis (2004) is the decline in both reading and writing ability and daily reading and writing habits among college students and graduates including teachers and education majors. In particular, teachers are not avid readers and writers (Brandt, 2004; Dobler, 2009). How can a teacher hope to instill a love of reading, the ability to comprehend, or robust vocabulary development into their instruction for K-12 students when they themselves do not possess these dispositions or skills? In addition, the researchers observed a decrease in the amount of reading their students were completing, especially beyond what was required such as textbooks and journal articles. As a result, we were interested in how they could foster a genuine interest in professional reading and cultivate critical thinking skills.

The objectives of the literacy bag project were : 1) To expose candidates to a diverse and eclectic range of perspectives on issues related to course content, 2) To

*Address correspondence to this author at the Florida Gulf Coast University, 10501 FGCU Blvd S., Fort Myers, FL 33965, USA; Tel: (239) 590-7783; Fax: (239) 590-7609; E-mail: 1serro@fgcu.edu encourage the practice of oral and written responses that build candidate confidence regarding professional knowledge, skills \& dispositions, and 3) To promote lifelong learning through reading and writing activities. The projects focused on short professional reading sections along with journaling and literature circle components.

\section{LITERATURE INFORMING THE STUDY}

\begin{abstract}
Aliteracy
Mikulecky (1978) was among the first literacy researchers to differentiate aliteracy from illiteracy. Aliterates are capable of reading and making meaning of text but they suffer from a lack of engagement or intrinsic motivation to read (Applegate \& Applegate, 2004; Asselin, 2004; Mikulecky, 1978). Scott (1996) defined aliteracy as a "lack of reading and writing habits especially in capable readers who choose not to read and write" (p.5). Aliterates possess the skills to successfully comprehend and create written texts; while illiterates do not possess the skills to successfully navigate or create texts. The component parts of literacy learning are numerous and varied yet a vast data bank exists into the strategies, activities, and lessons that support literacy development. Literacy rates (the ability to read) among Americans have increased over the past decade; yet findings by literacy educators and researchers such as Beers (1996), Nathanson et al., (2008), Voorhees et al., (2007) indicate aliteracy is a growing problem, among all segments of the population including educational professionals and teachers of literacy.
\end{abstract}


Research studies exploring the phenomena of aliteracy began in the decade of the seventies and focused on the literacy habits of elementary, middle school and high school students. Interest in the dispositions, behaviors, values and habits characterized by lifelong learning and literacy of education majors spawned a plethora of studies into their literacy habits and beliefs. Mueller's (1973) initial work into the literacy habits and practices of preservice teachers is supported by numerous later studies that indicated typical, undergraduate, preservice teachers possess only moderately positive attitudes about reading and writing, did not consider themselves to be good readers, did not enjoy reading, had not read a book within the last six months, and ranked reading low among choices for leisure activities (Applegate \& Applegate 2004; Draper et al., 2000; Frager, 1986; McKool \& Gespass, 2009; Mour, 1977; Powell-Brown, 2004; Smith, 1989; Turner et al., 2009; Young, 2006; Worden \& Noland, 1983).

Applegate and Applegate's (2004) multiyear study of undergraduate education majors at diverse United States universities supported those of earlier studies and coined a phrase, "The Peter Effect" to describe the phenomena of aliteracy among undergraduate education majors. Findings from their initial study (2004) indicated a lack of enthusiasm for personal reading and writing existed among $51.5 \%$ of the preservice teachers surveyed. Their most recent study (2014) found "strikingly low levels of enthusiasm for reading among undergraduate education majors with only $5.7 \%$ of students surveyed $(\mathrm{n}=1,000)$ classified as Engaged and Avid readers" (Applegate et al., 2014, p.188). Applegate, et al., (2014) concluded "the Peter Effect still persists among preservice teachers" (p.188).

Recent studies into the literacy habits and attitudes among graduate education majors obtained results similar to those of undergraduate students and support earlier findings of Mour (1997) and Mangieri (1981). Mour (1997) interviewed 400 graduate education majors who had jobs in education and found over half of the participants reported they read less than two books per year and they did no professional reading. Mangieri (1981) found out of the 571 teachers surveyed, $70 \%$ could not name a children's book and $89 \%$ could not name three or more activities teachers could use to promote recreational reading. Powell-Brown (2003) interviewed graduate students enrolled in a literacy methods course at a large Midwestern university and found aliteracy was prevalent among those students, especially practicing teachers. Powell-Brown's (2003) results were supported by the work of Nathanson et al., (2008) who administered the Literacy Habits Questionnaire, developed by Applegate and Applegate (2004) to 747 graduate students enrolled in a graduate school of education; most $(85 \%)$ of the participants were in-service teachers, the remainder were prospective teachers. Their findings were alarming; $17 \%$ of the total sample indicated they found little or no pleasure in reading, $48 \%$ reported they had read two or more books during the summer and $25 \%$ reported they had read one book in the summer. These findings that suggested leisure-time reading was not a priority for the sample. Results between enthusiastic readers and unenthusiastic readers revealed meaningful and statistically significant differences ( $X=247.6$, $d f=4, n=747, p=.000)$ in their summer reading habits. The survey indicated, $0 \%$ of the readers who characterized themselves as unenthusiastic readers $(n=139)$ were in the midst of reading a book. Although results from this study indicated some enthusiasm for reading as a leisure time activity was present and enthusiastic readers tended to read more books, the evidence of strong enthusiasm for reading among in-service and pre-service teachers was not present. Overall, results indicated teachers, as a group, did not have firmly established literacy habits. Although there is some disagreement among researchers concerning the consequences of aliteracy among preservice and practicing teachers; little controversy exits concerning the impact of teachers on their students.

\section{Teachers as Sponsors of Literacy}

Multiple studies over the past two decades identify the vital role teachers play in the development of engaged readers because engaged readers, who are intrinsically motivated to read for aesthetic and efferent purposes, do not develop by accident. Research by Kennedy (1998) identified the teacher as the major factor in determining the effectiveness of literacy instruction and Ruddell (1995) identified qualities of influential literacy teachers who made a profound impression on students. One quality stood out above all others; a love of reading, an approach which Rosenblatt (1978) labeled as an "aesthetic stance toward literacy" (p. 3). "Influential literacy teachers engage students in intellectual discovery, set high expectations and provide students with the tools to think deeply about what they read" (Applegate \& Applegate, 2014, p.190).

Teachers of all levels not only need to be effective readers but they also need a strong foundational knowledge about the literacy process (Applegate \& Applegate, 2004; Dobler, 2009). Much has been written about the literacy process; the ways people acquire and develop skills necessary to make meaning either as a reader or a writer and the "stance" readers embrace as they participate in the process. Quite often the debate on literacy methodology comes down to a choice between viewing literacy as a disconnected set of phonics skills delivered through a scripted phonics program or an "anything goes" approach. However, research determined the answer to this dilemma is not in the method; the answer is the teacher. The teacher's knowledge and lens through which teachers view the literacy process coupled with the "stance" teachers embrace in their teaching and reading seem to be the vital component to literacy pedagogy (Applegate \& Applegate, 2004; Daughdrill, 2000; Dobler, 2009; Labbo, 2007; Pardo, 2004; Rosenblatt, 1978).

\section{Motivation}

Brophy's (1986) and Deci's (1971) work on intrinsic and extrinsic motivators suggested that the teacher is a focal point for motivation and their work has been supported by experiences of classroom teachers. Classroom teachers recognized that their values and behaviors exert as powerful an influence on students' hearts and minds as the curriculum (Ruddell, 1995). More recently, Powell-Brown (2003) concluded teachers who possess a passion for reading and writing serve as "role models and literacy sparks for students" (p.288). Mour (1977) posited the logic in the assumption "a lifetime reading habit or the desire to read is 
transmitted to children via modeling by the significant adults in their lives" (p. 397). Of course, parents reside in the realm of significant adults, and rich research exists that validates the vital role parents play in leading children to embrace reading and writing enthusiastically (Baker \& Scher, 2002; Chen, 2008; Keskin, \& Bastug, 2014; Klauda, 2008; Klauda, 2009; Mour, 1977; Pomerants et al., 2007). However, children who lack role models for reading and writing in their personal world are particularly dependent on teacher modeling (Chen, 2008; Moje et al., 2008; Partin \& Hendricks, 2002).

Although significant adults who value reading and writing are not the only factor in motivating students of all ages to read; there exists a vast range of studies which posit the opportunity to choose one's reading material is directly related to motivation to read (Malloy et al., 2010). Respondents in multiple studies communicated the pivotal role choice played in their motivation to read. Allington (2001) stated "Students of all ages read more, understand more and are more likely to continue reading when they have the opportunity to choose what they read" (p.11). Multiple studies shared similar findings of Guthrie \& Wigfield (2000) who identified the two most significant instructional factors for improving reading motivation and comprehension were access to a multitude of books and personal choice in what to read. Choice offers greater opportunity that a reader will select a text they can read well, one which matches their reading ability, and Krashen (2004) provided significant evidence choice improved students' reading performance.

As researchers and professors in a teacher preparation program, we are and should be concerned about the prevalence of aliteracy among our preservice candidates and practicing graduates. We embrace and support the research that posits teachers who read widely in their private lives use a greater number of best practice strategies for literacy instruction (McKool \& Gespass, 2009; Dalhouse et al., 2011). Our concern led us to initiate this study to identify the existence of aliteracy among our students and mitigate its impact on their lives, their literacy practice, and the lives of their future and existing students.

\section{MATERIALS AND METHODOLOGY}

For the purposes of this study we utilized qualitative methods. As we are two university professors in a highstakes testing state, we designed our study within the context of a collective case study (Stake, 2000). Using this framework we discuss our classroom experiences, including the structure of our courses, assignments, and other relevant information. Reflective Ethnography (Ellis \& Bochner, 2000) was utilized to provide an overarching systematic method for analyzing the data along with constant comparative methods including reiterative readings of participants' original texts and member checking. Specifically, we examined our teaching lives, and although all courses were under similar certification requirements, they differed according to the level (graduate, undergraduate) and course content (introduction to reading, struggling readers, and reading assessment). We documented our conversations, emails, and meetings through researcher notebooks and shared our responses. We also examined the artifacts of our courses including syllabi, websites, and projects following the guidelines established by Patton (2002). Over 5 consecutive semesters we carefully reviewed student assignments and comments posted on discussion boards, other online activities, and response journals. In addition, we reflected on face-to-face class sessions and conversations that we had with our students. Credibility procedures followed Stake's (2000) suggestions for case study; the case was used to understand a research issue, multiple data sources were collected and triangulated, our researcher roles and views were apparent, a clear identification of the cases are presented, and themes are identified and discussed. The overarching research question was: How do Literacy Bag activities encourage critical thinking and professional reading?

\section{Participants}

Participants were a convenience sample of undergraduate and graduate students attending medium-sized state university situated in the southern United States and enrolled in courses taught by the researchers. There were 100 undergraduate education majors taking 4 reading methods courses required in their program of study. Each class consisted of undergraduate students majoring in Elementary, Early Childhood, Special Education and Secondary Education; classes were diverse in terms of age and gender. Graduate students numbered 32 in 2 literacy courses. No attempt at randomization or representativeness was made as case study methodology makes no claim of generalizability (Stake, 2000).

\section{Data}

Data included electronic survey responses to open-ended questions about reading habits, reading strategies used in their classrooms (graduate students), and literacy sponsors. All undergraduate and graduate students used journals to document what they read and their reaction to the readings. They also wrote a response to a peer who had read the same selection or book. Undergraduate students also created literacy autoethnographies with the major rationale being to identify significant literacy sponsors and explore literacy learning as it occurred in their lives. Other data sources were journal entries from all participants and researchers, and 12 individual videotaped interviews with undergraduate students. What follows are narratives chronicling the thinking and stories of each of the researchers. Their individual narratives reveal specifics in how they initiated the Literacy Bag research activity in their respective courses.

\section{Researcher Narrative: Graduate Reading Methods Course}

I have always believed that wide reading makes one a more reflective and creative thinker. Everything I read about topics such as literacy, motivation, learning, and creativity lead me to connections and new knowledge about my work with teachers and students. I wanted my graduate students to have the same exposure to interesting ideas beyond their textbook and journal articles. I wanted them to experience ideas from thinkers such as Gladwell (2008) and Pink (2009). I wanted them to read from other fields and from reflective pieces on teaching while giving them choice in what they read and how it related to their professional lives. I 
also wanted them to taste just a little bit of many books and savor the sweetness as Patricia Polacco shares in her book, Thank You, Mr. Falker (1998).

I have used Literacy Bags with many classes but for this study, I focused on two graduate classes in reading: Assessment in Literacy (17 students) and Instruction for Struggling Readers ( 15 students). Books were chosen by me that related to the course content in some way, even if it would require analysis and synthesis on the part of the student to find the connection. The assignment was completed weekly for approximately 8 weeks and accounted for $5 \%$ of their final grade in the course. The literacy bags were colorful canvas bags that included a book and journal notebook. Students chose a new literacy bag each week and were required to read one chapter from the book and reflect on that chapter in a journal. Before they wrote their reflection, they read the reflection by the previous student and wrote a response to that student. Some of the journals covered several semesters and different classes so the current students had an opportunity to read responses from different perspectives if they chose to do so. Each entry was signed and dated by the writer. At the beginning of class each week, students shared one or two insights they had gotten from the reading and reflection. At the end of the semester, students had the opportunity to re-read journals and see what responses had been written to them. This activity would often spark a reflective discussion about insights and connections to the books. As the final assignment, students were asked to reflect upon the literacy bag experience and evaluate its value to their teaching and professional growth.

I noticed that high achieving students (e.g. exceeded expectations on grading rubrics) would often read more than one chapter, sometimes finishing the whole book in a week. They would add titles to their "wish list" of books to purchase at a future date. Higher achieving students would make more connections between the course content, journal entries, class discussions and other assignments. They would also make connections among the various books in the literacy bags. In general, higher achieving students were more reflective in their written responses and sharing in class.

All of the course assessment comments by students at the end of the semester were positive except for two students out of the 22 reviewed. It should be noted that these two students were new teachers with less than one year of experience as paid professionals.

I believe the book bag project helped me to meet my goals. Students saw value and enjoyed the exposure to many authors and texts and were able to apply the ideas to their professional lives. Like Tricia, in Thank You Mr. Falker, (1998) they walked away with the sweet taste of honey. "The honey is sweet, and so is knowledge, but knowledge is like the bee who made the honey; it has to be chased through the pages of a book!"

\section{Researcher Narrative: Undergraduate Reading Methods Courses}

I have always viewed reading, any reading, as a playful activity. I classify myself as a ludic reader, an addict who spends a great portion of my time reading a wide range of material. My addiction serves me well in all facets of my life, especially in my capacity as a college literacy methods instructor. Although the students I teach are energetic and positive about their future profession; they reflect the characteristics attributed to aliteracy in the research literature. They do not practice the habits of daily reading and writing to support their ability to be highly effective literacy practitioners. More concerning, is the disconnect between their behavior and their staunch belief they can be effective teachers of reading and writing even though they do not like or choose to read and write. My reading and experience inform me of my need to become acquainted with my students' literacy histories and my need to integrate joyful reading into my courses. Literacy Bags became one of the ways I provided engaging and relevant reading and writing choices for my students which supported their autonomy in reading and writing. One of my goals was to keep them reading and I viewed choice as a cornerstone to achieving this goal.

Like my fellow researcher, books were chosen by me. Although, they related to the course content in some way, the variety of subjects crossed all genres and included books by Malcolm Gladwell, Barbara Ehrenreich, and Gene Glass. I was constantly aware of the possibility our generational differences might impact the project. Many choices required analysis and synthesis on the part of the student to find the connection to learning to read and reading in the content areas. The assignment was completed weekly for 12 weeks of the semester and accounted for $5 \%$ of their final grade in the course. Like my fellow researcher, the literacy bags were colorful canvas bags that included a book and journal. Students in my classes formed book study groups based on their interest. Each group was equal to the number of chapters in their chosen book. Each student in each group read one chapter in the book and reflected on that chapter in a journal. Before they wrote their reflection, they read the reflection by the previous student and wrote a response to that student. Some of the journals covered several semesters and different classes so the current students had an opportunity to read responses from different perspectives. Each entry was signed and dated. At the beginning of each class, students met in their groups, shared one or two insights that had emerged from their reading and reflection. Then, a short share back to the entire class was presented. The rationale for the share back was to motivate others in the class to share a "moment of clarity or a muddy point" from their reading. Rich discussions were often the result of the share back. At the end of the semester, students had the opportunity to re-read journals and see what responses had been written to them. This would often spark a reflective discussion about insights and connections to the books. As the final assignment, students were asked to reflect upon the literacy bag experience and evaluate its value to their teaching and professional growth.

Individual literacy autoethnographies provided me with information which helped me identify students with rich literacy histories; they would often read more than one chapter, sometimes finishing the whole book in a week. Like the graduate students, many would add titles to their "wish list" to purchase at a future date. Secondary majors were highly engaged in this strategy; but did not limit their 
Table 1. Summary of themes.

\begin{tabular}{|c|c|}
\hline Choice & $\begin{array}{l}\text { The literacy bag was a butterfly set free from a child's jar...I was so happy to have a variety of books to choose from (U). } \\
\text { I liked choosing instead of being forced to read the same thing as others (U). } \\
\text { I loved being able to choose a different professional text each week that I could take home and reflect on (G). }\end{array}$ \\
\hline Perspective Sharing & $\begin{array}{l}\text { It was meaningful to reflect on what we read using a journal then read the responses of others (U). } \\
\text { I really enjoyed reading a chapter and sharing information with other students. I enjoyed hearing their perspectives on books that I } \\
\text { would ultimately have the opportunity to read }(G) \text {. } \\
\text { The activity inspired some great conversations/controversies in class }(U) \text {. } \\
\text { Reading the responses of others allowed valuable insight into the book and how ideas translate to the classroom (G). } \\
\text { The discussions were amazing (U). } \\
\text { This exercise exposed us to many different viewpoints }(G) \text {. }\end{array}$ \\
\hline Motivation & $\begin{array}{l}\text { I actually went out and rented two of the choices so I could read them also (U). } \\
\text { This assignment made me feel like my opinion mattered (U). } \\
\text { The Literacy Bag was so cool, I can't wait to create some during student teaching and use them in my social studies classroom (U). } \\
\text { It made me want to get right back into my classroom and start to teach with these strategies that I learned from the literacy bags (G). } \\
\text { There were books that I purchased because I thought the ideas were so good (U). } \\
\text { I liked reading books I might not have normally read (G). } \\
\text { There were books that I probably would not have read if it was not form this course. I have purchased a couple of books that I } \\
\text { believe will assist me in my future career as a teacher (U). }\end{array}$ \\
\hline Classroom Application & $\begin{array}{l}\text { I can see where I could use this with } 4^{\text {th }} \text { or } 5^{\text {th }} \text { graders to encourage them to read in the content area. It would be like a content area } \\
\text { literacy circle. (U). } \\
\text { One of my students said that the new rule should be that everyone gets to read the "good part" of the book. He has read most of } \\
\text { my books and written in the reflection journal what page the "good part" of the book is (G). }\end{array}$ \\
\hline
\end{tabular}

$\mathrm{U}=$ Undergraduate; $\mathrm{G}=$ Graduate

reading to their content area of study. Higher achieving students (e.g. exceeded expectations on grading rubrics) would make more connections between the course text and content and the book bag chapters. They would also make connections among the books in the literacy bags. In general, higher achieving students and secondary majors were more reflective in their written responses and sharing in class.

I believe the book bag project helped me to meet my goals. Students enjoyed the exposure to many authors, their testimony validated the research on the power of choice, most were able to apply the ideas to their professional lives, and all students synthesized connections to their situated lives. Most valuable was the epiphany by Sara, "the assignment made me feel like my opinion mattered."

\section{RESULTS}

When reviewing the feedback reflection from the end of the semester, we found common themes in the responses of the candidates. The themes were choice, perspective sharing, motivation, and classroom application. Choice in selecting the book and chapters to read was a recurring theme. Choice was closely aligned with motivation as noted by Malloy et al. (2010), Allington (2001) and Guthrie \& Wigfield (2000). Participants found the literacy bags to be a non-judgmental activity with lots of choice. However, for two candidates without classroom experience, they saw no value in the activity and reported that "I like to read the first chapter before reading the book". For them it was difficult to jump into the book without starting at the beginning and choice was not motivating for them.
The responses emphasized the motivational power of being exposed to a variety of books. Since each book was different in content and approach, undergraduate and graduate students were motivated to explore new ideas. They felt empowered and believed that their opinion of the reading and its applications were valued.

Many shared the importance of perspective sharing and recognized the richness in discourse when a diversity of ideas were shared in face to face meetings and on-line discussions. Students liked reading other's responses, especially from previous semesters. In addition, the in class oral reports/sharing helped students to choose books to read and provided multiple opportunities to bring clarity to their muddiest points. One surprising outcome of the perspective sharing was that it built a sense of community in the classroom which went beyond the researchers hope that the students would become engaged in reading.

Undergraduates and graduates alike were able to generalize the literacy bag experience to their classroom teaching. Both graduate and undergraduate students recognized that reading and journaling incorporated reading, writing and responding to text in an authentic way. We found that many graduate students modified the strategy for their classroom teaching and incorporated the literacy bag experience for their students. Undergraduate students integrated the Literacy Bag as a means of parent communication during the field experience component of their literacy course. Others suggested that the experience could be incorporated into a professional development opportunity in their building. 


\section{CONCLUSION/DISCUSSION}

Studies by the National Endowment of the Arts (2004) indicate a general decline in the amount of leisure reading among Americans of every social and educational stratum and noted college attendance no longer guaranteed active reading habits. As literacy methods instructors in a teacher preparation institution we were disturbed that most of our students admitted their lack of desire to read and write. We set about to design course components to expose candidates to a diverse and eclectic range of perspectives on issues related to course content and provide opportunities to respond in both written and oral formats. Data from survey instruments, participant journals and face to face interviews indicate the Literacy Bag activity has potential to be an effective instructional technique for promoting professional reading and developing critical thinking at both the graduate and undergraduate levels.

The four themes to emerge from the data, importance of choice, perspective sharing, motivation and classroom application are all supported in the literature on evidenced based literacy practices. However, the current literacy climate often casts literacy teaching and learning as a purely cognitive process lacking the fire of literacy. Further, the words of the participants in this study suggested the fire of literacy was the door to deeper reading experiences. Their words supported ideas expressed by Vygotsky (1986) "an intimate connection between emotional reactions and cognitive human minds of significant others encourages the full development of a social being" (p.48).

Analysis of survey responses indicated Literacy Bag activities promoted a desire in students to continue professional reading beyond the course. Although the reading choices presented to the course participants were mostly related to their course content some were more eclectic in nature. The data indicted, regardless of the genre of the book in their bag, students approached the activity from an aesthetic stance; an aesthetic stance towards reading and writing is a necessary quality of effective literacy teachers (Allington, 2001; Draper et al., 2000). Data also revealed students engaged in critical thinking about course concepts via journal entries and verbal discussions. Students also expressed an awareness of diverse perspectives in the variety of texts read throughout the semester. When asked if instructors should continue implementing the Literacy Bag activity in future courses, $100 \%$ of respondents indicated to continue.

Based on these findings, we recommend instructors who want to engage students in professional reading and provide diverse perspectives on course content should implement the Literacy Bag activity. It is essential to include a wide range of genres and to allow student choice in selection of the texts. It is also important to provide opportunities for perspective sharing and making connections to classroom application. "Our society thrusts teachers in pivotal rolls of literacy instruction and motivation, if teachers cannot effectively promote a love of reading and writing then aliteracy will remain a concern for our schools and society at large carrying with it serious societal implications" (Applegate \& Applegate, 2004, p. 260). The most powerful components of this study were the authentic literacy experiences and participant voices. The lived experiences of these participants point to the dichotomy present in today's culture, the commonality of school literacy experiences juxtaposed with their unique individual interpretations. The power of student voices to elucidate socio-cultural and critical perspectives on literacy learning still matter in an era of literacy accountability.

\section{FUTURE RESEARCH}

Although the findings from this particular study indicated the implementation of a Literacy Bag course component was valuable and addressed the needs of these course participants we advocate for further research to address the following questions: Do students who engage in Literacy Bag activities develop a more thorough and persistent understanding of course concepts? Do students who engage in Literacy Bag activities apply course concepts more effectively in their own teaching practice? Do students who engage in Literacy Bag activities continue with their plans to engage in professional reading beyond the course? Future research should also examine students in a greater variety of courses.

\section{LIMITATIONS}

Results are generalizable only to students enrolled in courses similar to those included in this study. Although the number of participants was small, it is worth noting the number is within the sampling range for case study research (Stake, 2000). Although the study profited from the presence of two researcher coders, the lack of multiple coders was also a limitation of the study.

\section{CONFLICT OF INTEREST}

The authors confirm that this article content has no conflict of interest.

\section{ACKNOWLEDGEMENTS}

Declared none.

\section{REFERENCES}

Allington, R.L. (2001). What really matters to struggling readers: Designing research-based programs. New York: Londman.

Applegate, A., \& Applegate, M., (2014). The Peter Effect revisited: Reading habits and attitudes of college students. Literacy Research and Instruction, 53(3), 188-204.

Applegate, A., \& Applegate, M. (2004). The Peter Effect: Reading habits and attitudes of preservice teachers. The Reading Teacher, 57, 554563.

Asselin, M. (2004). Supporting sustained engagements with texts. Teacher Librarian, 31, 51-52.

Baker, L., \& Scher, D. (2002). Beginning readers' motivation for reading in relation to parental beliefs and home reading experiences. Reading Psychology, 23, 239-269.

Beers, K. (1996). "No time! No Interest! No Way!" The three voices of aliteracy. School Library Journal, 42(2), 30-33.

Brandt, D. (2004). Drafting U. S. literacy. College English, 66, 485-502.

Brophy, J. (1986). Teacher influences on student achievement. American Psychologist, 75, 631-662.

Chen, S. (2008). Who is the avid adolescent reader in Taiwan? The role of gender, family and teacher. Journal of Adolescent \& Adult Literacy, 52, 214-223.

Dalhouse, D.W., Dalhouse, A.D., Sibley, C.H., \& Nagwabi, R.C. (2011). Reading engagement of preservice teachers: Impact of a readingaloud initiative. Journal of Reading Education, 37, 33-39. 
Deci, E.I. (1971). Intrinsic motivation, extrinsic reinforcement and inequity. Journal of Personality and Social Psychology, 22, 113-120.

Dobler, E. (2009). Teachers as readers: How does my use of comprehension strategies influence my teaching of reading? Journal of Reading Education, 34, (2), 10-16.

Draper, M.C., Barksdale-Ladd, M.A., \& Radencich, M.C. (2000). Reading and writing habits Of preservice teachers. Reading Horizons, 40, 185-203.

Ellis, C., Bochner, A. (2000). Ethnographically speaking. Georgia: Atlanta Press.

Frager, A. (1986). Conquering aliteracy in teacher education. Journal of Teacher Education, 36, 55-58.

Gladwell, G. (2008). Outliers: The story of success. New York: Little Brown.

Guthrie, J.T., \& Wigfield, A. (2000). Engagement and motivation in reading. In: M.L. Kamil, P.B. Mosenthal, Pearson, \& R. Barr (Eds.), Handbook of Reading Research: volume III pp. 403-422. New York: Earlbaum.

Kennedy, M. (1998). Learning to teach writing: Does teacher education make a difference? New York: Teachers College Press.

Keskin, H.K., \& Bastug, M. (2014). A study of correlations among reading frequency, participation in reading environments and reading attitude. International Journal of Social Sciences and Education, 4(3), 560-568.

Klauda, S.L. (2008). The relations of children's perceived support for recreational reading from parents and friends to their motivation for reading (Doctoral Dissertation). Available from Proquest Dissertations and Theses Database. (UMI No. 3341404).

Klauda, S.L. (2009). The role of parents in adolescents' reading motivation and activity. Educational Psychology Review. 21(4), 325-363.

Krashen, S. (2004). The power of reading: Insights from the research $\left(2^{\text {nd }}\right.$ ed.). Portsmouth, NH: Heinemann.

Labbo, L. (2007). The golden rule should rule: Modest revelations on preservice teachers' explorations into cultural identity, prejudice, and empathy. Journal of Reading Education, 33(1), 40-46.

Malloy, J.A., Marinak, B.A., Gambrell, L.B.. \& Mazzoni, S.A. (2013). Assessing motivation to read: The Motivation to Read Profile Revised. The Reading Teacher, 67, 4.

Mangiere, J. (1981). Recreational reading: Do we practice what is preached? The Reading Teacher, 34, 923-925.

McKool, S. \& Gespass, S. (2009). Does Johnny's reading teacher love to read? How teachers'personal reading habits affect instructional practices. Literacy Research and Instruction, 48, 264-276.

Mikulecky, L. (1978). Aliteracy and a changing view of reading goals. Paper presented at the $23^{\text {rd }}$ Annual Meeting of the International Reading Association, Houston, Texas.

Mueller, D.L. (1973). Teacher attitudes toward reading. Journal of Reading, $17,202-205$

Moje, E.B., Overby, M., Tysvaer, N. \& Morris, K. (2008). The complex world of adolescent literacy Myths, motivations, and mysteries. Harvard Educational Review, 78, 107-154.
Mour, S. (1977). Do teachers read? Reading Teacher, 30(4), 397- 401.

Nathanson, S., Pruslow, J., Levitt, R.(2008). The reading habits and literacy attitudes of inservice and prospective teachers: Results of a questionnaire survey. The Reading Teacher, 59(4), 331-346.

National Endowment of the Arts. (2004). Reading at risk: A survey of literary reading in America. Retrieved, November, 2010, www.arts.gov.

Pardo, L.S. (2004). What every teacher needs to know about comprehension. The Reading Teacher, 58(3), 272-280.

Partin, K., \& Hendricks, C.G. (2002). The relationship between positive adolescent attitudes toward reading and home literary environment. Reading Horizons, 43(1), 61-84.

Patton, M. (2002). Qualitative research \& evaluation methods. Thousand Oaks, CA: Sage.

Pink, D. (2009). Drive: The surprising truth about what motivates us. New York: Riverhead Books.

Pomerantz, E.M., Moorman, E,A., \& Litwack, S.D. (2007). The how, whom, and why of parent's involvement in children's academic lives: More is not always better. Review of Educational Research, $77,373-410$.

Powell-Brown, A. (2003/2004). Can you be a teacher of literacy if you don't love to read? Journal of Adolescent \& Adult Literacy, 47, 284-288.

Rosenblatt, L.R. (1978). The reader, the text, the poem: The transactional theory of the literary work. Carbondale: Southern Illinois University Press.

Ruddell, R.B. (1995). Those influential literacy teachers: Meaning negotiators and motivation builders. The Reading Teacher, 48, 454463.

Scott, J.E. (1996). Self-efficacy: A key to literacy learning. Reading Horizons, 36, 195-213.

Senechal, M., \& Young, L. (2008). The effect of family literacy interventions on children's acquisition of reading from kindergarten to grade 3. Review of Educational Research, 78, 880907.

Smith, M.C. (1989). Reading attitudes of pre-service education majors. Reading Horizons, 29, 230-234.

Stake, R. (2000). Case Studies, pp. 435-54 in Handbook of Qualitative Research, edited by Norman K. Denzin and Yvonna S. Lincoln, Thousand Oaks, CA: Sage.

Turner, J.D., De Konty-Applegate, M., \& Applegate, A. (2009). Teachers as literacy leaders. The Reading Teacher, 63, 254-256.

Voorhees, S., Bausch, L., \& Inserra, A. (2007). Validation of the literacy representations survey: A tool for assessing reading and writing affect. Journal of Reading Education, 32(3), 28-34.

Vygotsky, L. (1986). Thought and language. Cambridge, MA: MIT Press.

Worden, T.W., \& Noland, R. (1983). An investigative study of teachers' reading preferences and related classroom practices. Journal of Reading Education. 10, 31-38.

Received: September 15, 2014

Revised: December 01, 2014

Accepted: February 02,2015

(C) Greene and Serro; Licensee Bentham Open.

This is an open access article licensed under the terms of the Creative Commons Attribution Non-Commercial License (http://creativecommons.org/licenses/by-nc/3.0/) which permits unrestricted, non-commercial use, distribution and reproduction in any medium, provided the work is properly cited. 